\section{NUMERICAL MODELLING OF MULTIPLE TUNED MASS DAMPER EQUIPPED WITH MAGNETO RHEOLOGICAL DAMPER FOR ATTENUATION OF BUILDING SEISMIC RESPONSES}

\author{
Afham Zulhusmi Ahmada, Aminudin Abua, Lee Kee Quena, Nor \\ A'zizi Othmana, Faridah Che In ${ }^{b}$ \\ a Malaysia-Japan International Institute of Technology (MJIIT), \\ Universiti Teknologi Malaysia, 54100, Kuala Lumpur, Malaysia \\ bCommerce Department Politeknik Melaka 75250 Melaka, \\ Malaysia
}

Article history

Received

26 April 2019

Received in revised form

20 July 2019

Accepted

24 July 2019

Published online

24 October 2019

*Corresponding author azulhusmi2@live.utm.my

\section{Graphical abstract}

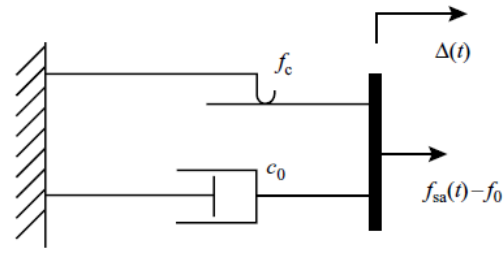

\begin{abstract}
TMD is basically designed to be tuned to the dominant frequency of a structure which the excitation frequency will resonate the structural motion out of phase to reduce unwanted vibration. However, a single unit TMD is only capable of suppressing the fundamental structural mode and for multimode control, more than one TMD is needed. In this study, a 3-storey benchmark reinforced structural building subjected to El Centro seismic ground motion is modelled as uncontrolled Primary Structure (PS) by including properties such as stiffness and damping. For the case of controlled PS which the passive mechanism is included to the system, optimum parameters of both TMD and Multiple TMD (MTMD) are designed to be tuned to the dedicated structural modes where the performance is dependent on parameters such as mass ratio, optimum damping ratio, and optimum frequency ratio. The input and output components of structural system arrangements are then characterized in the transfer function manner and then converted into state space function. For enhancement of the passive system, Magneto-Rheological (MR) damper is added to both single TMD and MTMD passive system. The response analysis is executed using both time history and frequency response analysis. From the analysis, semi-active case is the most effective mechanism with $99 \%$ displacement reduction for the third and second floors, and $98 \%$ for the first floor, compared to the uncontrolled case. It is concluded that the MR damper significantly contributed to the enhancement of the passive system to mitigate structural seismic vibration.
\end{abstract}

Keywords: Tuned mass damper, MR damper, Bingham Model, Rayleigh damping, RMS

\begin{abstract}
Abstrak
Secara asasnya, frekuensi TMD ditala bersesuaian dengan frekuensi dominan struktur untuk mengurangkan getaran yang tidak diinginkan. Walaubagaimanapun, mekanisme TMD hanya berkesan bagi mengawal mod struktur yang pertama dan untuk kawalan getaran multimod, lebih dari satu TMD diperlukan. Dalam kajian ini, bangunan penanda aras tiga tingkat yang mengalami gegaran gempa bumi El Centro direka bentuk sebagai struktur tanpa kawalan dengan mempertimbangkan unsur-unsur seperti kekukuhan dan redaman. Untuk kes struktur dengan kawalan yang melibatkan mekanisma kawalan pasif, parameter optimum untuk kedua-dua TMD tunggal dan TMD multimod direka bentuk berdasarkan kepada beberapa mod gegaran yang mana reka bentuk ini bergantung kepada nisbah jisim tambahan, nisbah redaman optimum, dan nisbah frekuensi optimum. Sistem input dan output struktur diperincikan dalam bentuk fungsi pemindahan dan ditukarkan dalam bentuk
\end{abstract}


fungsi ruang. Untuk menambahbaik sistem pasif, peredam Magneto-Rheological (MR) ditambah kepada sistem pasif tunggal TMD dan MTMD. Analisis tindak balas dilaksanakan dengan menggunakan analisis masa dan frekuensi respon kekerapan. Melalui analisis, kes separuh aktif adalah mekanisme yang paling berkesan dengan pengurangan anjakan sebanyak $99 \%$ untuk lantai tingkat ketiga dan kedua, dan $98 \%$ untuk tingkat pertama, berbanding dengan kes yang tidak terkawal. Secara kesimpulannya, peredam MR menyumbang secara signifikan terhadap penambahbaikan sistem pasif bagi mengurangkan getaran seismik struktur.

Kata kunci: Penampan jisim tertala, peredam MR, Model Bingham, peredam Rayleigh, RMS

(C) 2019 Penerbit UTM Press. All rights reserved

\subsection{INTRODUCTION}

Structural hazardous vibrations are caused by various means of dynamic excitations [1]. The most significant dynamic waves imposed to a structural system are commonly caused by nature such as wind, earthquake, and watercourse. Past destructive seismic events such as the Northridge (1994) and Kobe (1995) earthquakes demonstrated the importance of mitigating the natural hazards, reanalysing, and reinventing the existing control schemes. Importantly, strength depended design does not firmly justify that a building structure would be able to withstand hazardous loads without harming the occupants [2]. Therefore, to ensure that the structure responses in controlled dynamic manner, many researchers have carried extensive studies on alternative method upon traditional strength-based design method for controlling the primary system mass stroke to manageable intensity [3], [4], [5], and [6]. One of its kind is the TMD. A TMD system consists of an added secondary mass, functioning together with spring and damping elements to provide frequency-dependent damping mechanism in a primary structure [7]. In practice, TMD dissipate substantive vibration of the main structure without any connection to the ground and inherently stable to work during major earthquakes. The effectiveness of TMD can be determined by certain factors such as its dynamic characteristics, damping stroke, and TMD mass ratio to the modal mass.

In terms of operational mechanism, TMD will be tuned to the dominant natural frequencies of the primary structure to reduce unwanted vibration. However, this mechanism suffers certain drawbacks that are related to the sensitivity against operating environmental changes due to structural deterioration; subsequently, resulting to detuning [8]. TMD ability is restricted to reduce vibration components which is closed to the tuned frequencies and significantly limited to narrow bandwidth [9]. Therefore, it is inadequate for controlling structure under broadband excitation such as earthquakes. To overcome current disadvantages, various methods and mechanisms have been proposed to improve TMD performance reliability and robustness. One of the mechanisms is the implementation of MTMD. MTMD is a system consisting of several parallel TMDs. Since the major drawback of the single TMD is the detuning effect, the MTMD system provides a promising solution by appropriately distributing the tuning frequencies for assurance of effective vibration control.

Over recent decades, the development of MR damper has undergone significant achievement within various kind of industrial applications such as civil engineering, safety engineering, transportation, and others [10]. This rapid development is benefited from the characteristics of the MR dampers due to the wide range of controllable damping force, fast adjustable response, and low energy consumption [11]. MR dampers are categorized as nonlinear semi active control devices that exhibit hysteretic behaviour when subjected to dynamic load. Due to the drawbacks of passive TMD which was mentioned previously, many researchers have proposed adaptive mechanism to promote controllability of the TMD design [12]. The incorporation of active actuator to the passive TMD provides better vibration suppression. However, active force actuators require high consumption of power and cost [13]. Intricacies in maintenance make the utilization of active TMD less reliable and contributed to the necessity of providing semi active TMD control mechanism.

This manuscript will focus on the method of designing optimal parameters of TMD which is related to the determination of mass, damping, and frequency ratio. For better performance, semi active control scheme using MR damper is formulated for both TMD and MTMD passive control. The effectiveness of the proposed control mechanism is then modelled and analysed in the MATLAB subjected to time history analysis.

\subsection{LITERATURE REVIEW}

The control of structural vibrations caused by repetitive motions such as earthquake or wind can be implemented by various means. The system is designed by modifying auxiliary structural rigidities, masses, damping, or shape, which provide passive, 
active, semi active or hybrid counter forces. To date, some methods of structural control have successfully been used and many researchers have proposed new methods for extending applications and improving vibration control efficiency. Particularly for flexible tall building structures susceptible to strong winds, auxiliary damper devices such as viscous, viscous-elastic and plastic have been successfully employed to provide significant improvement to dissipation mechanism. One of the alternative approaches for controlling vibration of a taller building is the utilization of TMD which is an early developed dynamic vibration absorber, that primarily consists of auxiliary mass. In practice, the auxiliary mass is formulated in between one to five percent of the whole building weight and is normally located or retrofitted at the top of the building. The auxiliary system is tuned to the fundamental frequency of main structural mode to reduce its amplitude. The attenuation capability of the device can be designed using optimal tuning parameters including mass ratio and damping ratio. However, this strategy is effective only for stationary narrow band motions but less effective for broadband excitations such as earthquakes where the effects of transient is dominant.

TMD control devices have been implemented in multiple ways for skyscrapers, communication towers, office buildings, transportation and pedestrian bridges, against natural and human-made loadings [14], [15]. MTMD employed with variable stiffness and damping devices have been studied by many researchers for enhancement of control performance [16], [17], [15], [18]. The variable stiffness spring has been attached to the secondary mass and the frequency of each considered mode has been tuned within the interest bandwidth [19] and [20]. Various studies have specifically focused on Pendulum TMD (PTMD). [21], [15], [22], and [23] which examined the use of magneto-rheological dampers to compensate for the effects of detuning of PTMD mechanism. Due to mass uncertainties in the floors, passive nonlinear wire-rope springs are proposed by [24], [14] and [19] to introduce damping and stiffness characteristics into conventional PTMD. According to [20], the semi active TMD system showed that it is a reliable control scheme for a structure exposed to uncertainties of seismic excitations, mainly to avoid damages to the main structural components.

Since a single TMD is unable to suppress higher modes vibration, [15] and [25] initially found that an optimal design of MTMD should be able to perform better compared to a single TMD. To control buffeting problem of the Yangpu Bridge, 26] has implemented MTMD to overcome the impediment. [27], [28], [29] and [30] have demonstrated that non-uniformly distributed MTMD over-ruled the effectiveness of traditional MTMD. [31] presented the study on designing optimal TMD by optimizing its parametric configuration to search for an ideal controllability of structural displacement and acceleration. In order to study the optimal parameters of MTMD, [32] used genetic algorithm to identify the effect of mass ratio, numbers of TMDs, and external excitation to the performance of MTMD. It was found that the number of TMD is less influential compared to other factors. Numerical analysis by taking location and parameters of MTMD performed by [33] and [34] produced the results that demonstrated optimal locations of MTMD is less applicable with the increase of mass ratio.

Semi active control scheme is an adaptable control system that enables adjustable mechanism of its stiffness and damping to suppress different excitation [35]. Various semi active methods have been implemented to the passive TMD to achieve tuneable natural frequency using devices such as shape memory alloy, piezo stacks, piezo electric, and friction devices [9], [36]. Alongside with these devices is the MR damper which focused on electromagnetic power generation. [37] has investigated the effectiveness of semi active TMD with an MR damper to control responses of a tall building due to wind excitation. The analysis revealed that the control system performed similarly to the active TMD with a lower power consumption. In order to control fundamental vibration mode of a 21-storey office building, [38] developed a long stroke MR damper that reacts on a TMD The study revealed that for an equivalent key performance index, the proposed device is an economical solution compared to the passive TMD. [39] has proposed a novel Optimum Building Mass Damper (OBMD) by replacing passive fluid viscous dampers with MR damper for better seismic control performance. Both analytical and experimental procedures verified a superior improvement in structural seismic response mitigation. By referring to these studies, combining the adjustable features of the MR damper shows significant benefits for enhancing passive control performance.

A single TMD is designed in general to control fundamental vibration mode and dedicated to encounter seismic narrowband frequency closer to the fundamental frequency of a building structure. To enable vibration control capability of wideband seismic frequency, multiple TMD is needed for multimode control mechanism. This study presents the design of MTMD equipped with the MR damper. The arrangement of the MTMD is installed within the selected locations according to structural mode shape. To evaluate the proposed vibration control mechanism, an uncontrolled 3-storey building is modelled and excited with El Centro ground motion. For controlled mechanism, four different arrangements had been designed and labelled as passive TMD, passive MTMD, semi active TMD, and semi active MTMD. Root Means Square (RMS) displacement of the structural floors is considered for comparison and performance evaluation. It is observed that passive TMD performed well during free vibration of post-earthquake events, except for second the mode of vibration. Compared to the passive TMD, passive MTMD showed better performance where it had successfully suppressed structural vibration of all considered modes. Both 
passive configurations are more effective as they are equipped with MR dampers to enable significant effectiveness of controlling higher modes. Therefore, the MR damper contributed significantly to the efficacy of passive control to decrease the overall RMS structural displacement.

\subsection{METHODOLOGY}

The design of the TMD parameters depends on the properties of the structural modes which need to be controlled respectively. In this sub-section, the work flow of the study is initially established by modelling the structural equation of motion. The equation provided a numerical basis for analysing structural dynamic properties through the modal analysis method. The modal analysis of uncontrolled PS is performed to determine the structural modal parameters and the results are used in the design of the TMD parameters. The modelling of the MR damper is also formulated to form semi-active control strategy while the whole system is represented in state space to investigate the proposed structural control performance.

\subsection{Equation of Motion}

The PS arrangement considered for the study consists of a 3-storey Reinforced Concrete (RC) building structure subjected to horizontal ground excitation. The governing equation of the structure can be written as:

$$
[M] \ddot{X}+[C] \dot{X}+[K] X=-M\{\Gamma\} \ddot{X}_{g}
$$

where;

$$
[M]=\left[\begin{array}{cccc}
m_{1} & 0 & 0 & 0 \\
0 & \ldots & 0 & 0 \\
0 & 0 & m_{N} & 0 \\
0 & 0 & 0 & m_{d}
\end{array}\right]=\text { Mass Matrix , } \ddot{X}=\left[\begin{array}{c}
\ddot{x}_{1} \\
\ldots \\
\ddot{x}_{N} \\
\ddot{x}_{d}
\end{array}\right]=
$$

Acceleration Matrix

$$
[C]=\left[\begin{array}{cccc}
c_{1}+c_{2} & -c_{2} & 0 & 0 \\
-c_{2} & c_{2}+c_{3} & -c_{3} & 0 \\
0 & -c_{N} & c_{N}+c_{d} & -c_{d} \\
0 & 0 & -c_{d} & c_{d}
\end{array}\right]=\text { Damping }
$$

Matrix, $\dot{X}=\left[\begin{array}{c}\dot{x}_{1} \\ \cdots \\ \dot{x}_{N} \\ \dot{x}_{d}\end{array}\right]=$ Velocity Matrix

$$
[K]=\left[\begin{array}{cccc}
k_{1}+k_{2} & -k_{2} & 0 & 0 \\
-k_{2} & k_{2}+k_{3} & -k_{3} & 0 \\
0 & -k_{N} & k_{N}+k_{d} & -k_{d} \\
0 & 0 & -k_{d} & k_{d}
\end{array}\right]=\text { Stiffness }
$$

Matrix,$X=\left[\begin{array}{c}x_{1} \\ \ldots \\ x_{N} \\ x_{d}\end{array}\right]=$ Displacement Matrix

The equation of motion for free vibration of Multi Degree of Freedom system leads to the solution of eigenvalue problem. The solution of the eigenvalue problem is composed of eigenvalues and eigenvectors where the roots of eigenvalues are natural frequencies and the eigenvectors are mode shapes. In order to analyse structural responses, a typical 3-storey RC building structural parameters [40] is used as displayed in Table 1. In this study, the mass distribution of the structural system is replaced by a finite number of lumped masses of each individual story levels which are assumed to be connected by massless elastic damping members. Furthermore, it is also assumed that there is no rotation of the horizontal section of PS floor levels and the beams are rigid, relative to the columns. Therefore, the PS will response as a single horizontal translational degree of freedom and the lateral storey stiffness rely on the column stiffnesses of dedicated storey levels. These assumptions resulted the mass properties from Equation (1) to be a diagonal matrix while both damping and stiffness properties took a tridiagonal matrix form.

Table 1 Structural Properties of Primary Structure

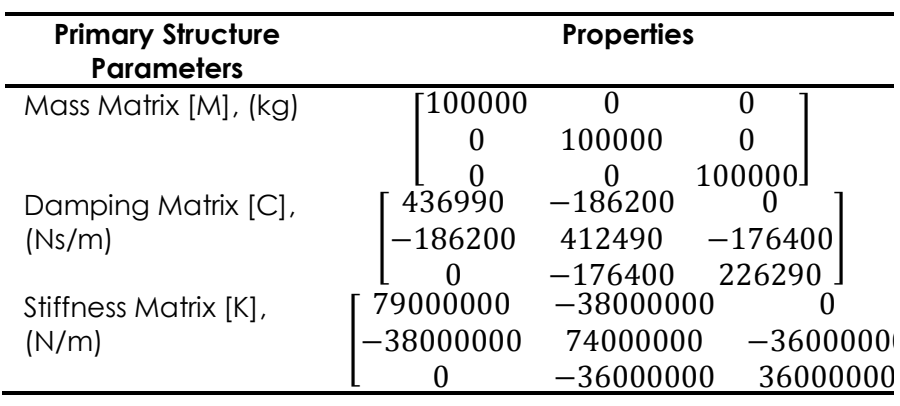

Here, the idealized elements of $m_{i}, c_{i}$, and $k_{i}$ are the mass, damping coefficient, and stiffness of the $i^{\text {th }}$ story, $x_{i}$ is displacement relative to the ground floor of the $i^{\text {th }}$ storey, the dots represent differentiation with respect to time, $\{\Gamma\}$ is a column vector of ones, and $\ddot{x_{g}}$ is the ground acceleration. Energy is stored by the system in the mass and spring element in the form of kinetic and potential energy. Energy enters the system through excitation and dissipated through structural damping. The damping matrix [C] is treated as a matrix that is proportional to the mass matrix [M] and stiffness matrix $[\mathrm{K}]$. Hence, the structural damping matrix is calculated according to the proportional Rayleigh damping as follow:

$$
[C]=\alpha_{1}[M]+\alpha_{2}[K]
$$

which the coefficient of $\alpha_{1}$ and $\alpha_{2}$ selection is taken into consideration that is fit to the primary structure for the first and second order natural frequencies $\left(\omega_{1}\right.$ and $\left.\omega_{2}\right)$ and damping ratios $\left(\xi_{1}\right.$ and $\left.\xi_{2}\right)$. Table 2 shows the numerical modal analysis of PS system to identify structural dynamic behaviour such as natural frequencies \& mode shapes. 
Table 2 Modal Parameters of Primary Structural System

\begin{tabular}{|c|c|c|c|}
\hline Parameters & \multicolumn{3}{|c|}{ Properties } \\
\hline $\begin{array}{l}\text { Natural } \\
\text { Frequencies } \\
(\boldsymbol{\omega}),(\mathrm{rad} / \mathrm{s})\end{array}$ & \multicolumn{3}{|c|}{$\begin{array}{l}\omega_{1}=8.8243, \omega_{2}=24.2650 \\
\omega_{3}=34.9763\end{array}$} \\
\hline $\begin{array}{l}\text { Time } \text { Period } \\
(\mathrm{T}),(\mathrm{s})\end{array}$ & \multicolumn{3}{|c|}{$\begin{array}{l}T_{1}=0.7120, T_{2}=0.2589, T_{3}= \\
0.1796\end{array}$} \\
\hline $\begin{array}{l}\text { Mode Shapes } \\
(\boldsymbol{\Phi})\end{array}$ & {$\left[\begin{array}{l}0.0010 \\
0.0019 \\
0.0024\end{array}\right.$} & $\begin{array}{c}0.0023 \\
0.0012 \\
-0.0019\end{array}$ & $\left.\begin{array}{c}0.0020 \\
-0.0023 \\
0.0009\end{array}\right]$ \\
\hline $\begin{array}{l}\text { Normalized } \\
\text { Mode Shape } \\
\text { (\$n) }\end{array}$ & {$\left[\begin{array}{l}1.0000 \\
1.8740 \\
2.3913\end{array}\right.$} & $\begin{array}{c}1.0000 \\
0.5295 \\
-0.8332\end{array}$ & $\left.\begin{array}{c}1.0000 \\
-1.1404 \\
0.4755\end{array}\right]$ \\
\hline $\begin{array}{l}\text { Damping } \\
\text { Ratio }(\xi)\end{array}$ & \multicolumn{3}{|c|}{$\begin{array}{l}\xi_{1}=0.0499, \xi_{2}=0.0697, \xi_{3}= \\
0.0928\end{array}$} \\
\hline
\end{tabular}

\subsection{Design of TMD}

Initially, a single TMD is designed separately to control specific structural modes. The TMD parameters represents as mass of the auxiliary $\left(m_{d}\right)$, damping coefficient of the auxiliary system ( $\left.c_{d}\right)$, and stiffness of the auxiliary system $\left(k_{d}\right)$. In terms of designing the TMD optimum parameters, there are several closed form expressions proposed by previous researchers, specifically to determine both optimum frequency ratio $\left(f_{d \text { opt }}\right)$ and optimum damping ratio $\left(\xi_{\text {d opt }}\right)$. Den Hartog [41] first developed closed form expression for optimum damper parameters to minimize steady state response of undamped primary structure subjected to main mass and base harmonic excitation depended on the pre-selected mass ratio, where the mass ratio $(\mu)$ is the ratio of the damper mass $\left(m_{d}\right)$ to the main structural mass $\left(m_{s}\right)$ :

$$
\begin{aligned}
& f_{\text {d opt }}=\frac{1}{1+\mu} \\
& \xi_{\text {dopt }}=\sqrt{\frac{3 \mu}{8(1+\mu)}}
\end{aligned}
$$

Warburton [42] formed several expressions to determine the TMD optimum parameters for white noise base excitation as an extended version of Den Hartog, stated as follow:

$$
\begin{aligned}
& f_{\text {d opt }}=\sqrt{\frac{1-\left(^{\mu} / 2\right)}{1+\mu}} \\
& \xi_{\text {dopt }}=\sqrt{\frac{\mu(1-\mu / 4)}{4(1+\mu)(1-\mu / 2)}}
\end{aligned}
$$

For the sole purpose of this study, curve fitting method performed by [43] and [44] have been implemented numerically for searching TMD and MTMD optimum parameters. The damping ratio of the primary structure $(\xi)$ is considered in the closed form expression and the curve fitting is used to find $f_{d \text { opt }}$ and $\xi_{d o p t}$ in terms of $\mu$ and $\xi$ :

$$
\begin{aligned}
& f_{\text {d opt }}=\frac{1}{1+\mu}\left[1-\xi \sqrt{\frac{\mu}{1+\mu}}\right] \\
& \xi_{\text {dopt }} \frac{\xi}{1+\mu}+\sqrt{\frac{\mu}{1+\mu}}
\end{aligned}
$$

Using these optimum damping parameters, the optimum value of TMD damping coefficient and stiffness can be determined by considering the following equations:

$$
\begin{aligned}
& k_{d o p t}=f_{d o p t}{ }^{2} \omega^{2} m_{d} \\
& c_{d o p t}=2 \xi_{d o p t} f_{d o p t} \omega m_{d}
\end{aligned}
$$

For the purpose of this study, the TMDs are tuned to different modes of the PS under base excitation. Parameters in Table 2 from the previous section are vital to justify TMDs' design and its installation locations. By referring to the table, it can be observed that the top floor will experience the largest deformation under base excitation. In this scenario, the placement of the TMD should be placed at the highest building floor to restrain the first mode shape. The modal mass can be calculated by normalizing the vector of the mode shape vector $\left(\phi_{n}\right)$. To determine the modal mass ratio $(\mu)$, damper mass of all modes is taken as 5 percent from the entire structural mass and divided to the contribution modal mass $\left(M_{n}\right)$ of each mode shape

\begin{tabular}{|c|c|c|c|c|}
\hline Mode & $\begin{array}{c}\text { TMD } \\
\text { Location }\end{array}$ & $\begin{array}{r}m_{d} \\
(\mathrm{~kg})\end{array}$ & $\begin{array}{c}c_{\text {opt }} \\
(\mathrm{Ns} / \mathrm{m})\end{array}$ & $\begin{array}{r}k_{\text {opt }} \\
(\mathrm{N} / \mathrm{m})\end{array}$ \\
\hline $\begin{array}{l}\text { Mode } \\
1 \\
\text { TMD1 }\end{array}$ & Third Floor & $\begin{array}{l}1500 \\
0\end{array}$ & 102675 & 1070866 \\
\hline $\begin{array}{l}\text { Mode } \\
2 \\
\text { TMD2 }\end{array}$ & First Floor & $\begin{array}{l}1500 \\
0\end{array}$ & 219634 & 7360682 \\
\hline $\begin{array}{l}\text { Mode } \\
3 \\
\text { TMD3 }\end{array}$ & $\begin{array}{l}\text { Second } \\
\text { Floor }\end{array}$ & $\begin{array}{l}1500 \\
0\end{array}$ & 355309 & 15380598 \\
\hline
\end{tabular}
vectors. The optimum parameters for these mode shape can be determined numerically using the known values of modal mass ratio $(\mu)$ and internal damping ratios $(\xi)$. Table 3 and Table 4 summarized the optimum damping parameters for both the TMD and MTMD cases.

Table 3 Optimum Parameter of passive TMD

Table 4 Optimum Parameter of passive MTMD

\begin{tabular}{lcccc}
\hline Mode & $\begin{array}{c}\text { TMD } \\
\text { Location }\end{array}$ & $\begin{array}{c}\boldsymbol{m}_{\boldsymbol{d}} \\
(\mathbf{k g})\end{array}$ & $\begin{array}{c}\boldsymbol{c}_{\text {opt }} \\
(\mathbf{N s} / \mathbf{m})\end{array}$ & $\begin{array}{c}\boldsymbol{k}_{\text {opt }} \\
(\mathbf{N} / \mathbf{m})\end{array}$ \\
\hline Mode & Third Floor & 5000 & 24773 & 376432 \\
$\mathbf{1}$ & First Floor & 1000 & 130102 & 5177217 \\
MTMD1 & & 0 & & \\
Mode & Second & 5000 & 88619 & 5692655 \\
$\mathbf{2}$ & Floor & 1000 & 130102 & 5177217 \\
MTMD2 & First Floor & 0 & & \\
\hline
\end{tabular}




\begin{tabular}{lcccc}
\hline Mode & $\begin{array}{c}\text { TMD } \\
\text { Location }\end{array}$ & $\begin{array}{c}\boldsymbol{m}_{\boldsymbol{d}} \\
(\mathbf{k g})\end{array}$ & $\begin{array}{c}\boldsymbol{c}_{\text {opt }} \\
(\mathbf{N s} / \mathbf{m})\end{array}$ & $\begin{array}{c}\boldsymbol{k}_{\text {opt }} \\
(\mathbf{N} / \mathbf{m})\end{array}$ \\
\hline Mode & Third Floor & 5000 & 24774 & 376432 \\
$\mathbf{3}$ & Second & 1000 & 213000 & 10783639 \\
MTMD3 & Floor & 0 & & \\
\hline
\end{tabular}

The design parameters of passive TMDs from Table 3 are carried out according to the corresponding modes. By referring to the normalized mode shape of all modes $\left(\emptyset_{n}\right)$, it is clear that the third floor experienced the largest steady state amplification. Since then, in order to control the initial mode, the placement of the TMD should be at the top floor. The same manner applies to other modes which fundamentally, the TMD must be located at the floor which revealed the highest value mode shape vector. Importantly, the MTMD differed in manner where two TMD are tuned to different modes to produce system capability to control multiple structural modes.

\subsection{MR Damper Modelling \& State Space Representation}

Primarily, for performance adjustment of the vibratory system, semi-active damper using controllable magnetorheological (MR) fluid is combined with TMD passive vibration dissipation system. Initially, the dynamic behaviour modelling of the semi-active device is formulated to assist overall mechanism analysis. Since MR fluid exhibits a high degree of nonlinearity, several mathematical models have been proposed by [45] and [46]. Most common mathematical models include Bingham and BoucWen models, which in this study, Bingham model is implemented due to its simplicity. In formulation basis, the MR damper consists of Coulomb friction element that is parallel to viscous element, where the output force of MR damper is written as follow:

$$
F_{e}=k_{e} x_{p}+c_{e} \dot{x}_{p}+F_{M R} \operatorname{sgn}\left(\dot{x}_{p}\right)
$$

Figure 1 revealed the dynamic behaviour of MR damper respectively, where the first term of Equation (11) represents the spring force from the gas compliance, the second term refers to damping force due to the viscosity of MR fluid, and the last term is damping force due to the yield stress of the MR fluid. To perform numerical analysis of both uncontrolled and controlled primary structure, the systems are modelled through Simulink environment as illustrated in Figure 2. The seismic input is inserted to the structural model that is represented in state space and all structural responses are transferred to the controller through acceleration sensors.

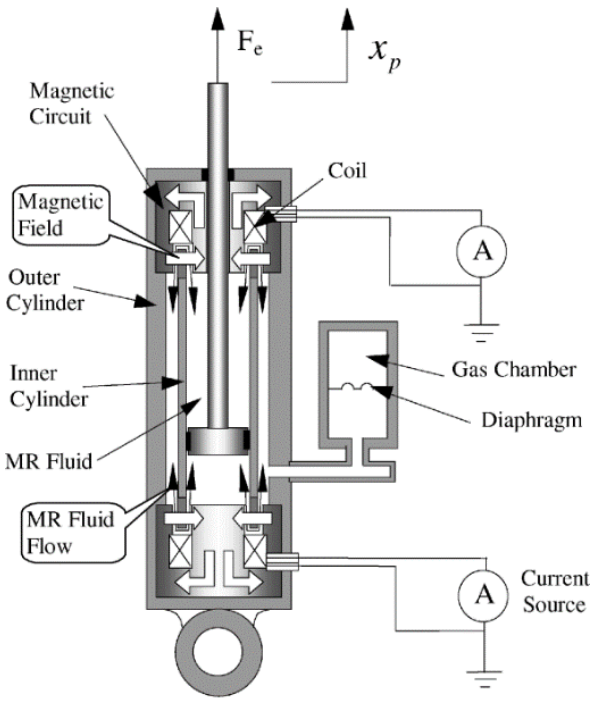

Figure 1 MR damper dynamic behaviour

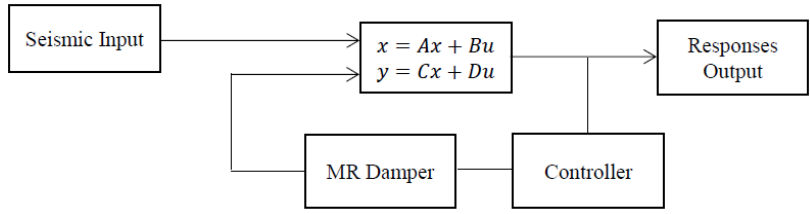

Figure 2 Simulink Model in MATLAB

Equation (12) defined the state space equations for both uncontrolled and controlled primary structure respectively:

$$
\begin{aligned}
\dot{\boldsymbol{x}}(t) & =[A] \boldsymbol{x}(t)+[B] \boldsymbol{u}(t) \\
\boldsymbol{y}(t) & =[C] \boldsymbol{x}(t)+[D] \boldsymbol{u}(t)
\end{aligned}
$$

where $\boldsymbol{x}(t)=\{\{x(t)\},\{\dot{x}(t)\}\}^{T}=$ state vector, $\boldsymbol{y}(t)=$ output vector, and

$$
\begin{aligned}
& {[A]=\left[\begin{array}{cc}
{[0]} & {[I]} \\
-[M]^{-1}[K] & -[M]^{-1}[C]
\end{array}\right]=\text { system matrix, (14) }} \\
& {[B]=\left[\begin{array}{c}
{[0]} \\
{[M]^{-1}}
\end{array}\right]=\text { input matrix, }[D]=[0]=\text { direct }}
\end{aligned}
$$

\subsection{RESULT \& FINDINGS}

Purposely to initiate step response analysis of the proposed passive control arrangements, a transient excitation is applied to the systems in time domain. The input signal has a limited duration which decay exponentially after a certain time. The procedure is mainly referred to the evaluation of system performance through both percentage of overshoot (PO) and settling time $\left(T_{s}\right)$ of structural response. Percentage of overshoot is a measure of magnification in the structural response to sudden 
change in applied force. The PO values are important to determine any interference within the design of the control system. To measure the system's ability to return to an equilibrium state, the settling time measurement must be orderly to analyse the time taken for a system to descend within a certain percentage of steady state value.

Table 5 summarized the overall analysis of the step and frequency response for both uncontrolled and controlled primary structure. The integration of TMD and MTMD for all mode shapes vector is subjected to step input that reduced the percentage of overshoot and settling time of all primary system floors compared to the uncontrolled case. However, when comparing between single and multiple TMD, MTMD arrangement, it further revealed a significant reduction on the percentage of overshoot excepted for second mode of the first and third floor which the values are unchanged. Subsequently, the settling time reduction for the MTMD depreciated for the first mode control but performed well for the other two modes, compared to the single TMD caseThis scenario portrays that the existence of TMD at the specified floor relatively stabilized the maximum peak displacement at the beginning of the time which contributed to a controllable structural peak magnitude while the suppression time of controlled structural vibration is improved to achieve steady state response. From the analysis, the passive control transient response characteristics have been successfully justified for both single and multiple TMD in terms of $\mathrm{PO}$ and $T_{s}$.

Table 5 Summary of Step \& Frequency Response forUncontrolled \& Controlled Primary Structure (a) Percentage Overshoot (b) Settling Time

\begin{tabular}{|c|c|c|c|c|}
\hline \multirow[t]{2}{*}{ Mode } & \multirow[t]{2}{*}{ Floor } & \multicolumn{3}{|c|}{$\begin{array}{l}\text { Overshoot } \\
\text { (\%) }\end{array}$} \\
\hline & & UC & $\underset{T M D}{C}$ & $\underset{\text { MTMD }}{C}$ \\
\hline \multirow{3}{*}{1} & 1 & 80 & 60 & 36.6 \\
\hline & 2 & 85.3 & 63.9 & 47.9 \\
\hline & 3 & 86.8 & 65.1 & 48.3 \\
\hline \multirow{3}{*}{2} & 1 & 80 & 55.8 & 56 \\
\hline & 2 & 85.3 & 71.4 & 60.7 \\
\hline & 3 & 86.8 & 71.3 & 71.4 \\
\hline \multirow{3}{*}{3} & 1 & 80 & 44.9 & 43.9 \\
\hline & 2 & 85.3 & 47.8 & 43.3 \\
\hline & 3 & 86.8 & 74.5 & 46.1 \\
\hline
\end{tabular}

(a)

\begin{tabular}{|c|c|c|c|c|c|c|}
\hline \multirow[t]{2}{*}{ Mode } & \multirow[t]{2}{*}{ Floor } & \multicolumn{5}{|c|}{$\begin{array}{l}\text { Settling Time } \\
\text { (s) }\end{array}$} \\
\hline & & UC & $\begin{array}{c}C \\
T M D\end{array}$ & $\begin{array}{c}\text { Redu } \\
\text { ction } \\
(\%)\end{array}$ & $\underset{\text { MTMD }}{C}$ & $\begin{array}{c}\text { Redu } \\
\text { ction } \\
(\%)\end{array}$ \\
\hline \multirow{3}{*}{1} & 1 & 8.59 & 2.43 & 71.7 & 3.16 & 63.2 \\
\hline & 2 & 8.61 & 2.44 & 71.7 & 3.82 & 55.6 \\
\hline & 3 & 8.93 & 2.45 & 72.6 & 3.82 & 57.2 \\
\hline \multirow{3}{*}{2} & 1 & 8.59 & 6.28 & 26.9 & 2.5 & 70.9 \\
\hline & 2 & 8.61 & 6.91 & 19.7 & 4.52 & 47.5 \\
\hline & 3 & 8.93 & 6.91 & 22.6 & 5.47 & 38.7 \\
\hline \multirow{3}{*}{3} & 1 & 8.59 & 3.19 & 62.9 & 2.01 & 76.6 \\
\hline & 2 & 8.61 & 3.55 & 58.8 & 1.86 & 78.4 \\
\hline & 3 & 8.93 & 3.93 & 56 & 2.18 & 75.6 \\
\hline
\end{tabular}

(b)

Consequently, Frequency Response Function (FRF) of a structure can be represented in different forms to identify vibration modes. In reference to Figure 3 , the FRF from the Bode diagram of the system transfer function depicted different behaviour between uncontrolled and controlled condition for the passive TMDI case manifested by the resonance peak in $\mathrm{dB}$ unit. By observing the figure, the tuned parameter of TMD1 minimized the maximum magnitudes of uncontrolled structure at each resonant frequency, which observably reduced significantly for the first natural frequency. The anti-resonances can be observed because it is approximately located between two modes (1.94 and $4.91 \mathrm{~Hz}$ ). This phenomenon is caused by relation between phases and not related to any global property of the primary structure. The anti-resonance of controlled TMDI case lifted the phase from $-139^{\circ}$ to $-75^{\circ}$ for the first point and from $-128^{\circ}$ to $-126^{\circ}$ at the other point.

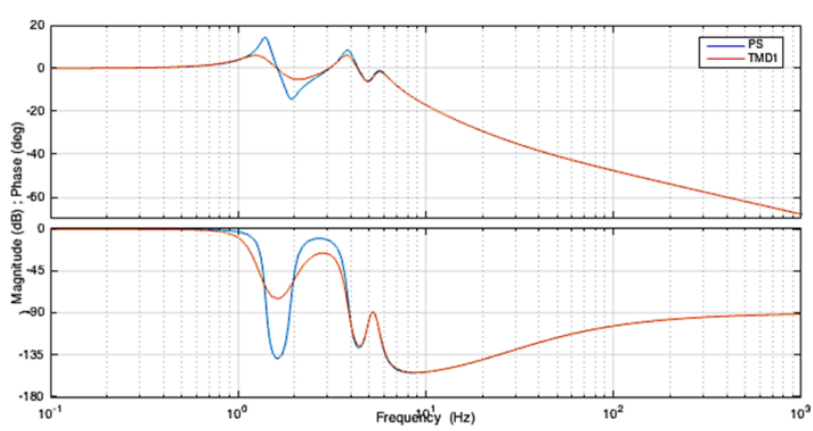

Figure 3 Comparison of Bode Diagram of Uncontrolled \& Controlled First Floor PS System (TMD1) 


\subsection{Structural Pole-Zero Maps}

The transfer function provides a basis for understanding the structural system response qualitative characteristics without solving the whole differential equation. Generally, the poles and zero of a transfer function can be represented by plotting their locations into a complex s-plane of real and imaginary axes which both zero and pole marked as (o) and $(x)$. In reference to Figure 4, complex conjugate of pole pairs $(\sigma \pm j \omega)$ are all located within the left-half of the s-plane. Those complex conjugate pole pairs were combined to engender decaying sinusoid response components with some overshoot in the form of $A e^{-\sigma t} \sin (\omega t+\emptyset)$, where both amplification $(A)$ and phase $(\varnothing)$ are determined first by the initial condition, $\sigma$ is the rate of decay, $\omega$ depicts the frequency of oscillation. The uncontrolled primary structure shows that the system has 3 poles with 2 zeros while the controlled system exhibited 3 poles and 3 zeros with the existing of vibration attenuation system located at the top floor. Overall, the system can be considered as an underdamped system which the damping ratio is equivalent to $0<\xi<1$. The form of the complex conjugate pair as follow:

$$
\text { pole1,pole } 2=-\xi \omega_{n} \pm j \omega_{n} \sqrt{1-\xi^{2}}
$$

From Figure 4 , it is observed that the poles located at a distance of $\omega_{n}$ from the origin and at the angle of $\pm \cos ^{-1}(\xi)$. This means that the underdamped pair poles are placed on a semi-circle radius which is defined by $\omega_{n}$ at an angle value defined by $\xi$. Table 6 and 7 depict the qualitative characteristics of the uncontrolled and controlled primary systems. The stability of the linear primary system can directly be determined from the transfer function. A linear system is considered stable asymptotically if all the components in the homogenous response decay from a finite set of initial conditions to zero as time increases. The control system is considered as a stable system since all poles lie to the left of the real axis $(j \omega)$ which means any transient response will eventually reach equilibrium.

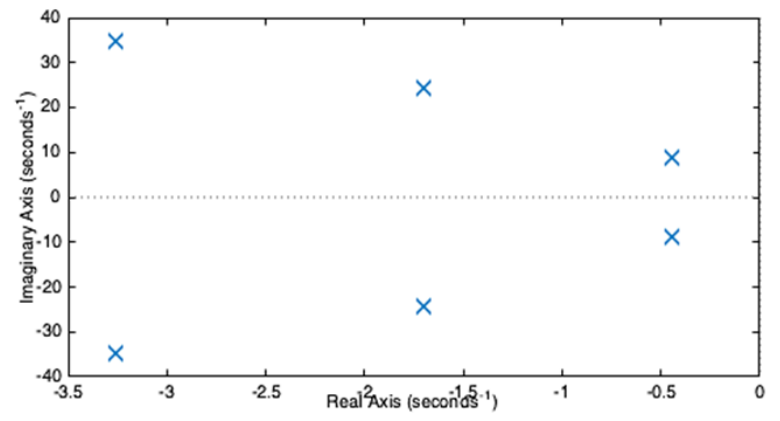

Figure 4 Pole Zero Map of PS System
Table 6 Pole Zero of Uncontrolled \& Controlled Primary Structure

\begin{tabular}{|c|c|c|c|}
\hline \multirow[t]{2}{*}{ Mode } & \multirow[t]{2}{*}{ Floor } & \multicolumn{2}{|c|}{$\begin{array}{c}\text { Pole } \\
(\sigma \pm \omega i)\end{array}$} \\
\hline & & TMD & MTMD \\
\hline \multirow{3}{*}{1} & 1 & $-1.55 \pm 7.97 i$ & $-0.995 \pm 4.3 \mathrm{i}$ \\
\hline & 2 & $-2.3 \pm 24.1 \mathrm{i}$ & $-2.65 \pm 26.4 \mathrm{i}$ \\
\hline & 3 & $-3.2 \pm 8.62 i$ & $-2.94 \pm 28.9 i$ \\
\hline \multirow{3}{*}{2} & 1 & $-0.549 \pm 5.09 i$ & $-0.701 \pm 6.42 i$ \\
\hline & 2 & $-3.38 \pm 29.4 i$ & $-2.81 \pm 28.9 i$ \\
\hline & 3 & $-14 \pm 56.3 i$ & $-32 \pm 87.3 i$ \\
\hline \multirow{3}{*}{3} & 1 & $-0.977 \pm 8.94 \mathrm{i}$ & $-1.69 \pm 7.32 i$ \\
\hline & 2 & $-1.85 \pm 21.2 \mathrm{i}$ & $-1.68 \pm 20.8 i$ \\
\hline & 3 & $-20.2 \pm 57.2 \mathrm{i}$ & $-3.43 \pm 34.31 i$ \\
\hline \multirow{3}{*}{$\begin{array}{l}\text { W/O } \\
\text { TMD }\end{array}$} & 1 & $-0.441 \pm 8.81 i$ & - \\
\hline & 2 & $-1.7 \pm 24.2 \mathrm{i}$ & - \\
\hline & 3 & $-3.26 \pm 34.8 i$ & - \\
\hline
\end{tabular}

Table 7 Natural Frequency \& Damping Ratio of Uncontrolled \& Controlled Primary Structure

\begin{tabular}{|c|c|c|c|c|c|}
\hline \multirow[t]{2}{*}{ Mode } & \multirow[t]{2}{*}{ Floor } & \multicolumn{2}{|c|}{$\begin{array}{c}\text { Natural } \\
\text { Frequency } \\
\left(\omega_{n}\right) \mathrm{rad} / \mathrm{s}\end{array}$} & \multicolumn{2}{|c|}{ 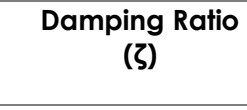 } \\
\hline & & TMD & MTMD & TMD & MTMD \\
\hline \multirow{3}{*}{1} & 1 & 8.12 & 4.41 & 0.19 & 0.225 \\
\hline & 2 & 24.2 & 26.5 & 0.095 & 0.1 \\
\hline & 3 & 9.19 & 29.1 & 0.348 & 0.101 \\
\hline \multirow{3}{*}{2} & 1 & 5.11 & 6.46 & 0.107 & 0.109 \\
\hline & 2 & 29.6 & 29 & 0.114 & 0.097 \\
\hline & 3 & 58 & 92.9 & 0.242 & 0.344 \\
\hline \multirow{3}{*}{3} & 1 & 8.99 & 7.52 & 0.109 & 0.225 \\
\hline & 2 & 21.3 & 20.9 & 0.087 & 0.0803 \\
\hline & 3 & 60.6 & 34.5 & 0.333 & 0.0994 \\
\hline \multirow{3}{*}{$\begin{array}{l}\text { W/O } \\
\text { TMD }\end{array}$} & 1 & 8.82 & - & 0.05 & - \\
\hline & 2 & 24.3 & - & 0.07 & - \\
\hline & 3 & 35 & - & 0.0932 & - \\
\hline
\end{tabular}

\subsection{Response Of Primary Structure Due To Ground Excitation}

In order to investigate the effectiveness of the proposed control algorithm, comparative numerical analysis is carried out for both the uncontrolled and controlled primary systems subjected to El-Centro seismic motion. Figure 5 depicted the displacement output of the third-floor primary structure for various control arrangement. It can be seen that the control responses of the structure are improved on both peak and the RMS displacement magnitude which benefited from the MR damper. The percentage 
reduction values of RMS displacement for passive TMD1 is $43 \%$ while semi active TMDl is $83 \%$. Nevertheless, the passive MTMDI revealed a $12 \%$ response reduction and the semi-active MTMD1 is $83 \%$. However, these data only covered the first mode of structural response which is insufficient to justify the most effective control strategy to cater all modes.

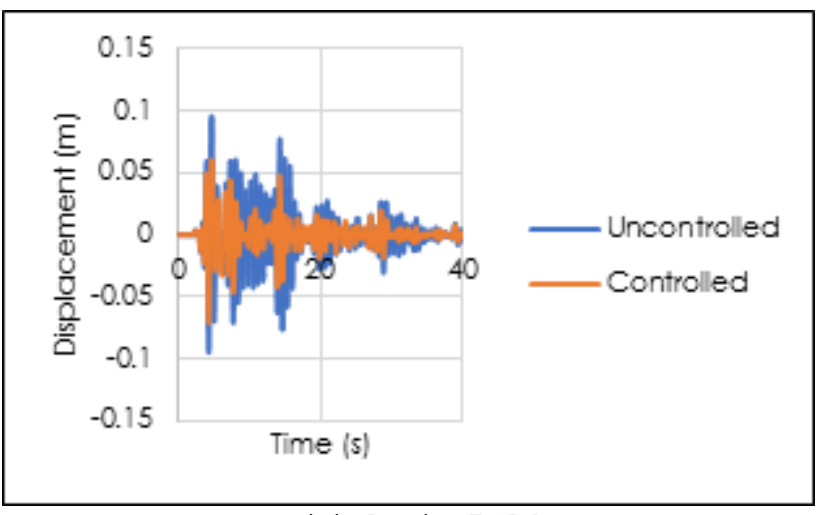

(a) Passive TMD1

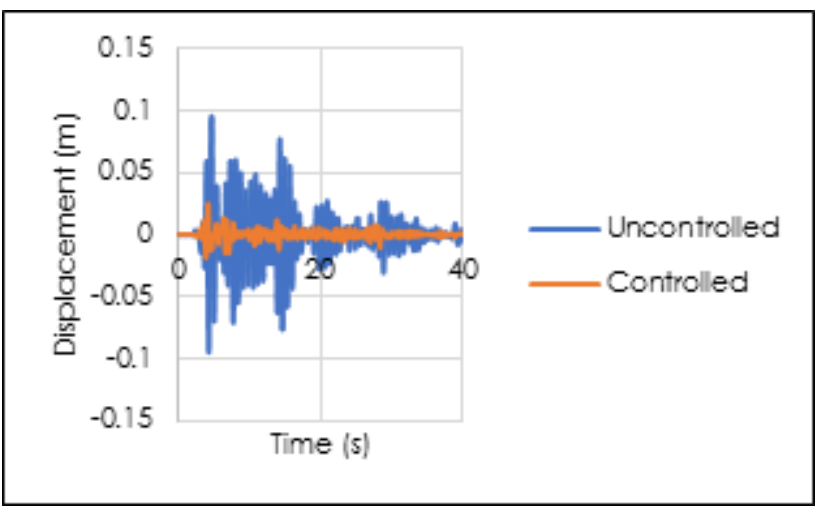

(b) Semi Active TMD1

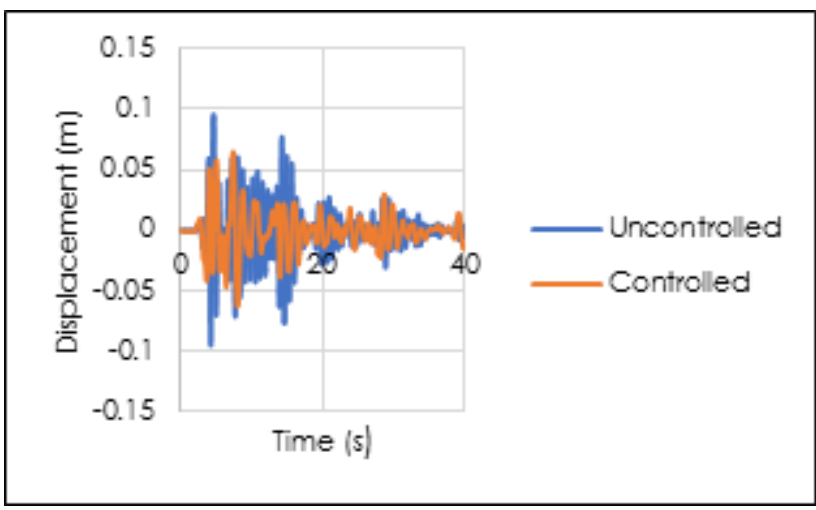

(c) Passive MTMD1

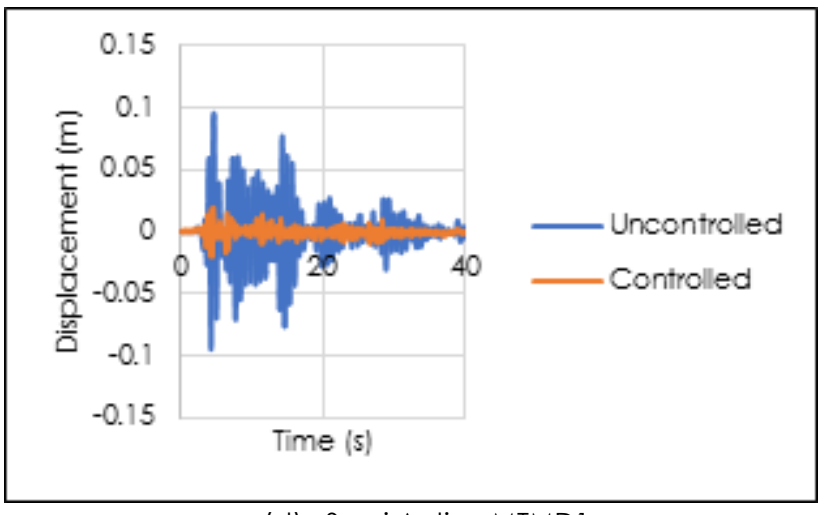

(d) Semi Active MTMD1

Figure 5 Comparison of Uncontrolled \& Controlled Third Floor Structural Response due to El-Centro Ground Acceleration

Figure 6 shows the RMS displacement of all control strategies considering all three structural modes. From the observation of passive control strategy in Figure 6(a) and 6(c), MTMD3 surpassed the overall performance of TMD3 especially in terms of RMS displacement of the third floor with different performance percentage at 20 percent. By referring to Table 5(a) of step response analysis, the PO of the first and third floor is unchanged for second mode passive control strategy. However, it is observed from Figure $6(a)$ and $6(b)$ that in terms of RMS displacement, passive MTMD2 shows better performance compared to the passive TMD2. This situation explains how the RMS value provides a meaningful interpretation on the performance of control mechanism throughout the time history of seismic event, which when compared to the PO, it is only referred to the initial input changes.

For the semi-active control strategy, both TMD and MTMD arrangement satisfy the borderline of uncontrolled condition of primary structure. Semiactive TMD3 performs very well with slightly tight difference to the semi-active TMD2 with the effectiveness percentage of just 2 percent for the top floor RMS displacement. In a different manner, there is a slightly 12 percent difference on the performance percentage between the semi-active control strategies of MTMD3 and semi-active MTMD1.

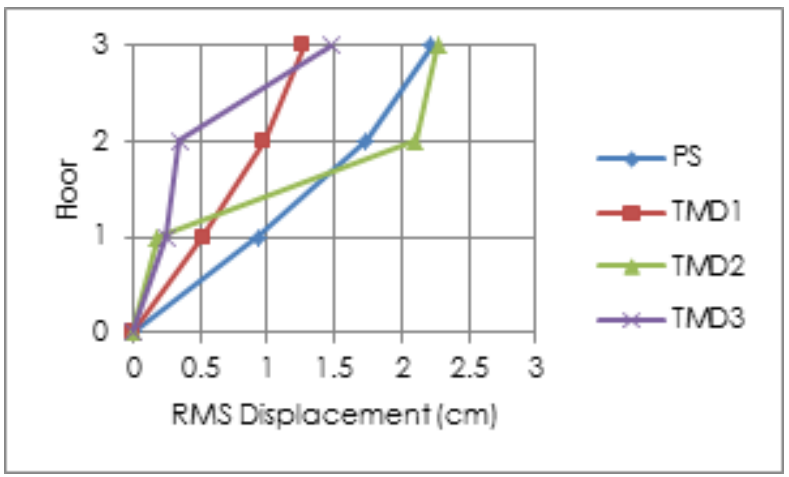

(a) Passive TMD 


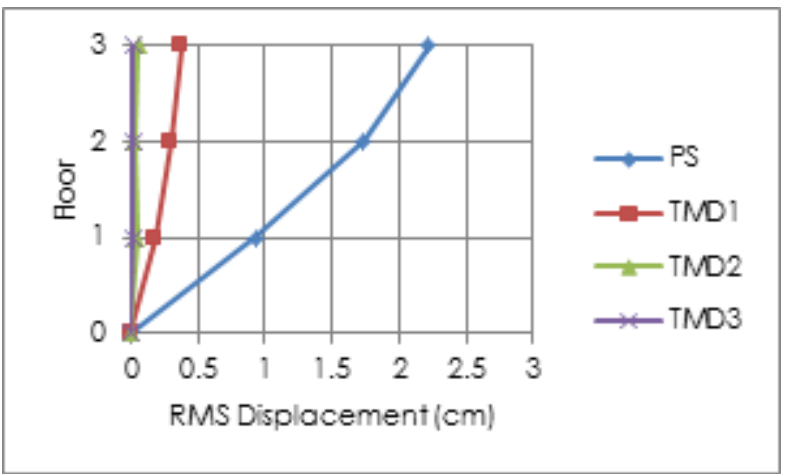

(b) Semi Active TMD

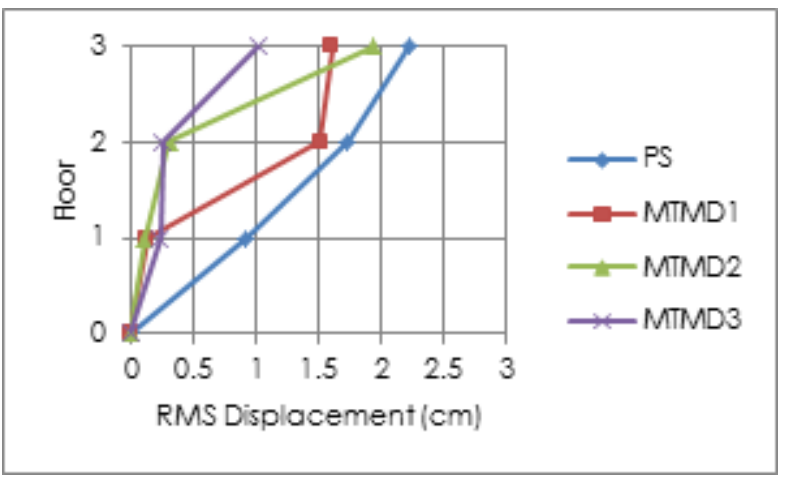

(c) Passive MTMD

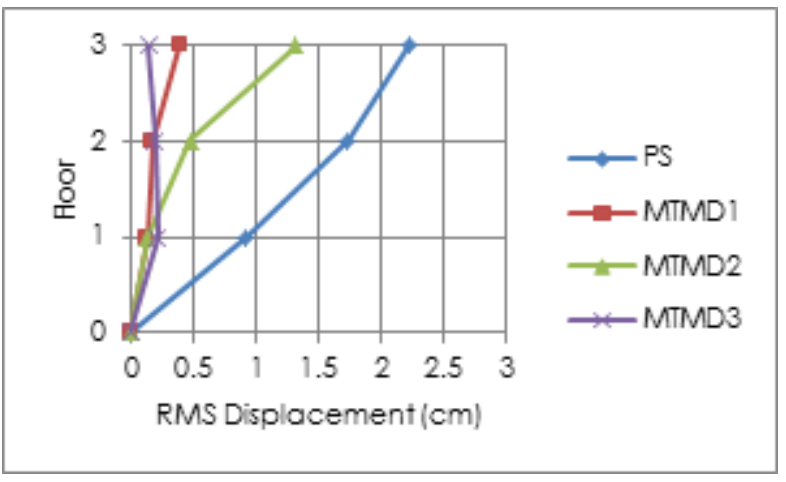

(d) Semi Active MTMD

Figure 6 RMS Displacements of Control Mechanisms

\subsection{CONCLUSION}

The proposed numerical design of the various TMD control strategies to attenuate the responses of a three-storey building under earthquake excitation is presented in this paper. From the results, it can be deduced that the proposed passive MTMD has improved the performance of passive single TMD to control higher mode structural response due to ElCentro ground seismic input. The designed MTMD is more efficient for the RMS response reduction. In comparing the analysis between passive TMD and passive MTMD cases, it is concluded that for TMD2, the existence of single TMD at the first floor is unable to suppress the displacement of other structural floors and it only deteriorates the effectiveness of the control mechanism. This situation explains the need of more than just a single TMD in terms of controlling multimode structural vibration. In overall, the performance of both the TMD and MTMD is improved with the combination of MR damper to produce semi-active vibration control.

\section{References}

[1] A. V. Hadian, A. A. Mutalib, and S. Baharom. 2013. Seismic Behaviour of Base Isolation System using Lead Rubber Bearing. Jurnal Teknologi. 65(2): 79-88.

[2] S. Thenozhi and W. Yu. 2013. Advances in Modeling and Vibration Control of Building Structures. Annu. Rev. Control. 37(2): 346-364.

[3] A. Xiang, P.;Nishitani. 2015. Optimum Design and Application of Non-traditional Tuned Mass Damper Toward Seismic Response Control with Experimental Test Verification. Int. Assoc. Earthq. Eng. 44(March): 2199-2220.

[4] J. F. Wang and C. C. Lin. 2016. Development of Optimal Design Theory for Series Multiple Tuned Mass Dampers Considering Stroke and Multiple Structural Modes. J. Phys. Conf. Ser. 744(1).

[5] S. Y. Kim and C. H. Lee. 2018. Optimum Design of Linear Multiple Tuned Mass Dampers Subjected to White-noise Base Acceleration Considering Practical Configurations. Eng. Struct. 171 (May): 516-528.

[6] S. Y. Kim and C. H. Lee. 2018. Optimum Design of Linear Multiple Tuned Mass Dampers Subjected to White-noise Base Acceleration Considering Practical Configurations. Eng. Struct. 171 (June): 516-528.

[7] P. Tan, C. J. Fang, C. M. Chang, B. F. Spencer, and F. L. Zhou. 2015. Dynamic Characteristics of Novel Energy Dissipation Systems with Damped Outriggers. Eng. Struct. 98: 128-140.

[8] B. Wen, M. A. Moustafa, and D. Junwu. 2018. Seismic Response of Potential Transformers and Mitigation Using Innovative Multiple Tuned Mass Dampers. Eng. Struct. 174(July): 67-80.

[9] S. Nagarajaiah and E. Sonmez. 2007. Structures with Semiactive Variable Stiffness Single/Multiple Tuned Mass Dampers. J. Struct. Eng. 133(1): 67-77.

[10] G. Hu, W. Zhou, and W. Li. 2015. A New Magnetorheological Damper with Improved Displacement Differential SelfInduced Ability. Smart Mater. Struct. 24(8): 087001.

[11] S. Cetin, E. Zergeroglu, S. Sivrioglu, and I. Yuksek. 2009. Adaptive Control of Structures with MR Damper. 2009 IEEE Int. Conf. Control Appl. 1: 60-65.

[12] S. Sun et al. 2018. Development of Magnetorheological Elastomers-based Tuned Mass Damper for Building Protection from Seismic Events. J. Intell. Mater. Syst. Struct. 29(8): 1777-1789.

[13] G. Xinchun, H. Yonghu, R. Yi, L. Hui, and O. Jinping. 2015. A Novel Self-powered MR Damper: Theoretical and Experimental Analysis. Smart Mater. Struct. 24(10): 105033.

[14] S. Elias and V. Matsagar. 2017. Research Developments in Vibration Control of Structures Using Passive Tuned Mass Dampers. Annu. Rev. Control. 44: 129-156.

[15] A. J. Roffel and S. Narasimhan. 2016. Results from a FullScale Study on the Condition Assessment of Pendulum Tuned Mass Dampers. J. Struct. Eng. 142(1): 1-12.

[16] T. Asai, C. M. Chang, B. M. Phillips, and B. F. Spencer. 2013. Real-time Hybrid Simulation of a Smart Outrigger Damping System for High-rise Buildings. Eng. Struct. 57: 177-188.

[17] T. E. Saaed, G. Nikolakopoulos, J.-E. Jonasson, and H. Hedlund. 2015. A State-of-the-art Review of Structural Control Systems. J. Vib. Control. 21 (5): 919-937.

[18] Shih, Y. C., Shih, W. Y., Lyan, Y. L., Chih, H. P. 2016. A Leverage-type Stiffness Controllable Mass Damper for Vibration Mitigation of Structures. Struct. Control Heal. Monit. 25(10): 1-17. 
[19] Y. A. Lai, L. L. Chung, C. S. W. Yang, and L. Y. Wu. 2018. Semiactive Phase Control of Tuned Mass Dampers for Translational and Torsional Vibration Mitigation of Structures. Struct. Control Heal. Monit. 25(9): 1-22.

[20] A. Giaralis and A. A. Taflanidis. 2018. Optimal Tuned Massdamper-inerter (TMDI) Design for Seismically Excited MDOF Structures with Model Uncertainties based on Reliability Criteria. Struct. Control Heal. Monit. 25(2): 1-22.

[21] A. J. Roffel and S. Narasimhan. 2014. Extended Kalman Filter for Modal Identification of Structures Equipped with a Pendulum Tuned Mass Damper. J. Sound Vib. 333(23): 60386056.

[22] H. He, W. Wang, and H. Xu. 2017. Multidimensional Seismic Control by Tuned Mass Damper with Poles and Torsional Pendulums. Shock Vib.

[23] M. D. Christie et al. 2019. A Variable Resonance Magnetorheological-fluid-based Pendulum Tuned Mass Damper For Seismic Vibration Suppression. Mech. Syst. Signal Process. 116: 530-544.

[24] C. M. Chang, S. Strano, and M. Terzo. 2016. Modelling of Hysteresis in Vibration Control Systems by means of the Bouc-Wen Model. Shock Vib. 2016(1).

[25] Y. Li, Z. Zong, X. Huang, J. Xia, and L. Liu. 2017. Experimental Study on Mechanical Properties of High Damping Rubber Bearing Model. IOP Conf. Ser. Earth Environ. Sci. 61 (1).

[26] M. Gu, S. R. Chen, and C. C. Chang. 2001. Parametric Study on Multiple Tuned Mass Dampers for Buffeting Control of Yangpu Bridge. J. Wind Eng. Ind. Aerodyn. 89(11-12): 9871000.

[27] Y. Q. Ni, Y. Xia, W. Lin, W. H. Chen, and J. M. Ko. 2012. SHM Benchmark for High-rise Structures: A Reduced-order Finite Element Model and Field Measurement Data. Smart Struct. Syst. 10(4): 411-426.

[28] O. El-Khoury, C. Kim, A. Shafieezadeh, J. E. Hur, and G. H. Heo. 2016. Mitigation of the Seismic Response of Multi-span Bridges using MR Dampers: Experimental Study of a New SMC-based Controller. J. Vib. Control. January.

[29] S. J. Wang, B. H. Lee, W. C. Chuang, and K. C. Chang. 2018. Optimum Dynamic Characteristic Control Approach for Building Mass Damper Design. Earthq. Eng. Struct. Dyn. 47(4): 872-888.

[30] L. Yong-An; L.Kuan-Hua; C. Lap-Loi; W. Lai-Yun. 2016. Suspension-type Tuned Mass Dampers with Varying Pendulum Length to Dissipate Energy. Struct. Control Heal. Monit. December 2015.

[31] M.-H. Chey and J.-U. Kim. 2012. Parametric Control of Structural Responses Using an Optimal Passive Tuned Mass Damper Under Stationary Gaussian White Noise Excitations. Front. Struct. Civ. Eng. 6(3): 267-280.

[32] F. Palacios-Quiñonero, J. Rubió-Massegú, J. M. Rossell, and H. R. Karimi. 2017. Advanced Computational Design of Shared Tuned Mass-inerter Dampers for Vibration Control of Adjacent Multi-story Structures. Partially supported by the
Spanish Ministry of Economy and Competitiveness under Grant DPI2015-64170-R/FEDER. IFAC-PapersOnLine. 50(1): 13366-13371.

[33] M. M. . Gunay S. 2015. Measuring Bias in Structural Response Caused by Ground Motion Scaling. Int. Assoc. Earthq. Eng. 44(June 2009): 657-675.

[34] R. Frans and Y. Arfiadi. 2015. Designing Optimum Locations and Properties of MTMD Systems. Procedia Eng. 125: 892898,

[35] K. Ghaedi, Z. Ibrahim, H. Adeli, and A. Javanmardi. 2017. Invited Review: Recent Developments in Vibration Control of Building and Bridge Structures. J. Vibroengineering. 19(5): 3564-3580.

[36] Y. L. Xu and B. Chen. 2008. Integrated Vibration Control and Health Monitoring of Building Structures Using Semi-active Friction Dampers: Part I-Methodology. Eng. Struct. 30(7): 1789-1801.

[37] J. Kang, H. S. Kim, and D. G. Lee. 2011. Mitigation of Wind Response of a Tall Building using Semi Active Tuned Mass Damper. Struct. Des. Tall Spec. Build. 20(October 2010): 552565.

[38] R. Zemp, J. Carlos, D. Llera, H. Saldias, and F. Weber, Development of a Long-stroke MR Damper for a Building with Tuned Masses. Smart Mater. Struct. 25(10): 1-17.

[39] Y. F. Liu, T. K. Lin, and K. C. Chang. 2018. Analytical and Experimental Studies on Building Mass Damper System with Semi-active Control Device. Struct. Control Heal. Monit. 25(6): 1-19.

[40] S. Rajasekaran. 2009. Structural Dynamic of Earthquake Engineering. Woodhead Publishing Limited.

[41] R. S. Jangid. 1999. Optimum Multiple Tuned Mass Dampers for Base-excited Undamped System. Earthq. Eng. Struct. Dyn. 28(9): 1041-1049.

[42] G. B. Warburton. 1982. Optimun Absorber Parameters for Various Combinations of Response Reductions Parameters. Earthq. Eng. Struct. Synamics. 381401 (10): 381-401.

[43] F. Sadek, B. Mohraz, A. W. Taylor, and R. M. Chung. 1997. A Method of Estimating the Parameters of Tuned. 26(July 1996): 617-635.

[44] M. S. Rahman, K. Hassan, and S. Chang. 2016. Adaptive Multiple Tuned Mass Dampers Based on Modal Parameters for Earthquake Response Reduction in Multi-story Buildings. Adv. Struct. Eng. 20(9): 1375-1389.

[45] P. Xiang and A. Nishitani. 2016. Structural Vibration Control with the Implementation of a Pendulum-type Nontraditional Tuned Mass Damper System. J. Vib. Control. June 2015: 3-4.

[46] R. W. K. Chan, J. K. K. Yuen, E. W. M. Lee, and M. Arashpour. 2015. Application of Nonlinear-Autoregressive-Exogenous Model to Predict the Hysteretic Behaviour of Passive Control Systems. Eng. Struct. 85: 1-10. 